\title{
Revisiting Creative Accounting in the Context of Islamic Economic and Finance System
}

\author{
Ali Malik ${ }^{1}$, Nasser I. Abumustafa ${ }^{1} \&$ Haider Shah $^{2}$ \\ ${ }^{1}$ QFBA-Northumbria University, Doha, Qatar \\ ${ }^{2}$ Hertfordshire Business School, University of Hertfordshire, United Kingdom \\ Correspondence: Ali Malik, QFBA-Northumbria University, QFC Tower 2, West Bay, Doha, Qatar. Tel: \\ 974-6626-7093. E-mail: m.malik@northumbria.edu.qa
}

\author{
Received: November 11, $2018 \quad$ Accepted: December 5, $2018 \quad$ Online Published: January 30, 2019 \\ doi:10.5539/ass.v15n2p80 \\ URL: https://doi.org/10.5539/ass.v15n2p80
}

\begin{abstract}
The paper investigates the possibility and spread of creative accounting (CA) related practices in the emerging financial system based on Islamic ideology and economics principles. Analytical methodology has been adopted in order to answer the research questions with a view to improving clarity of concepts. At the doctrinal level, there is little likelihood for practices associated with creative accounting as Islamic finance forbids use of misleading information in business transactions. At the operational level, however, factors like adoption of conventional accounting standards, use of income smoothing practices, and the flexibility in subjective interpretation of scripture based laws (Sharia) open up possibilities for the new financial system to be permeated by creative accounting practices. Islamic finance can be plagued by the pernicious effects of CA practices, therefore, any complacency on the part of advocates of Islamic finance can be misplaced. If practices like creative accounting continue to prevail in Islamic financial system, it will negatively affect the image of Islamic finance as an ethical, just, equitable and fair system. The authors have made a contribution by drawing attention of the research community to the neglected but important issue of creative accounting by critically analysing it and arraying the doctrinal view against the operational view.
\end{abstract}

Keywords: creative accounting, Islamic finance, Sharia, ethics

\section{Introduction}

Creative accounting (CA hereafter) attracted considerable attention from authors and researchers in the accounting profession as a noticeable issue within the framework of business ethics (Jones, 2011; Uysal, 2010). The high profile cases such as Enron and WorldCom received wide media coverage and further stoked up interest of analysts and researchers in business ethics, in general, and CA, in particular. At times calls are made to remedy the greed driven capitalist model of accounting with a more ethical basis of accounting (Mainelli, 2012; Kamla, 2009). Of late, Islamic finance (IF hereafter) has presented itself as a new model of finance which claims to be not based on greed but on pursuance of social justice, holism, knowledge development and ethical objectives (Kamla, 2009). In this paper, we review the IF model using the creative accounting issue as an analytical lens in order to find the degree to which IF can remedy the unethical tendencies that are associated with CA practices. The paper comprises five sections. After this introduction, in section 2 we carry out a review of the literature on CA. In section 3, research methodology has been provided and in section 4 we discuss the role of accounting and accountants in Islam. In section 5, we critically examine the IF model and investigate the possibilities of IF model remedying the detrimental effects of CA. In section 6, we sum up our analysis and draw final conclusions.

\section{Contemporary Literature on CA}

The term 'CA' became popular during the 1980s in the backdrop of high profile corporate scandals. The nature and magnitude of these scandals were such that CA attracted media and public interest on a very wide scale (Minkow, 1995). Tweedie and Whittington (1990) even went on to suggest that 'the recent problems of accounting standard-setting in the UK revolve around what is sometimes called 'creative accounting' ( $p$. 88). In 2000-2010 the corporate world shook to its core with the failure of business giants like Enron and Lehman Brothers generating widespread awareness of the potentially disastrous results of CA practices. The term CA has 
no specific definition. More generally, this usually refers to the tools and techniques that companies use to transform financial statements figures from what they are objectively reported to what they desire them to be by taking advantage of flexibility and loopholes in the existing rules and standards (Naser, 1993; Breton \& Taffler, 1995; Mulford \& Comiskey, 2002; De La Torreo, 2009; Jones, 2011; Popescu \& Nisulescu, 2013; Yaday, 2014). Creativity in accounting is generally considered a healthy notion as it makes the discipline proactive and responsive to developments in the environment in which it operates (Tweedie \& Whittington, 1990). The term, however, has largely been associated with deceitful motives and it has been contended that its continuous used might put in danger the integrity and usefulness of accounting profession (Samuel et al., 1989).

Contrary to outright fraud or other illegal activities, CA operates on the margins of legality and it is not per se against the letter of the law. It is, however, against the spirit of the law. The same debate currently prevails around concepts of tax avoidance and tax evasion. The CA slides and slithers through the areas where standards allow alternative treatment and/or use of judgement (see for example, Griffith, 1995; Barreveld, 2002; Yaday, 2014). To put it differently, it is not so much the actual use of CA but rather the motives behind it that decides whether any particular instance of CA is being used in a positive or a negative manner, especially if it indeed violates the spirit of the law, no matter even if it complies with the letter of the law. The CA does become unacceptable (even illegal) when it is employed with expressed intention of conveying false and misleading financial statement information to those who intend to use them for economic decision making (Gowthorpe \& Blake, 1998; Mulford \& Comiskey, 2002; Schilit, 2002, De La Torreo, 2009). The sophistication of capital markets combined with that of corporate financial management has encouraged some CA activities that have been flagged as clearly unacceptable (Tweedie \& Whittington, 1990; Crumbley \& Apostolou, 2003; Jones, 2011; Popescu \& Nisulescu, 2013). The recent scandals in financial institutions have led many to assert that use of CA is linked to bad governance (Spellman, 2012).

While there is an increasing evidence to indicate that CA not only exists, but is rapidly increasing (Alexander \& Archer, 2003; Jones, 2011; Yaday, 2014), its potential use of misleading the users of accounting information is a contentiously worrisome issue. For example, due to CA practices, the economic decisions based on misleading information may result in inefficient allocation of scarce resources not merely on a particular investment scale, but on national and international scales. This inefficient allocation of economic resources, if allowed to become widespread, may eventually impede economic growth and economic development in general (see for example, Alexander \& Archer, 2003).

\section{Research Methodology}

This is a conceptual paper that investigates some of the key assumptions and principles of IF with regards to the issue of CA. The following research question motivate and guide this paper:

"To what extent can IF be adversely affected by the practices which are commonly associated with CA?"

In order to answer the research question, the analytical methodology route (Wilson, 1969; Norreklit, 2000) is adopted which helps in improving clarity of concepts by revisiting old concepts with fresh insights. The paper endeavours to contribute to our understanding of core concepts of IF by considering the analytical question at both doctrinal and operational levels. For the doctrinal perspective, reliance was based on the verses of the Holy Quran, Islamic jurisprudence based views and official publications of the Islamic financial institutions (IFIs) establishment such as central banks of the countries that promote IF (e.g Malaysia, Pakistan). For operational perspective, the news items that have appeared in the last five years about actual working of Islamic Financial Institutions were investigated besides benefitting from views expressed by various sceptics of IF in academic publications and online available mainstream discussions.

Revisiting the issue in IF by using CA as an analytical lens is interesting because IF not only projects itself as an ethical financial system (Blackaby, 2008) but has also shown significant growth in the last few decades. To what extent do the doctrinal beliefs overlap with the operational level realities is a question which when answered can also help in making a contribution to the debate over sustainability of the IF in terms of long term growth and expansion.

Given next is a summary of the basic principles and architecture of IF model which then will be extended to the analysis of the role of CA.

\section{Accounting and Accountants in the Islamic Financial Model}

Although the modern structure of IF did not emerge until 1950s in the form of first generation of Islamic banks in Egypt and Malaysia, the basic tenets can be traced back to the origins of Islam in the $7^{\text {th }}$ century Arab society. The first fully fledged interest free bank was established in Dubai as Dubai Islamic Bank back in 1974 (Karbhari 
et al., 2004). The IF industry has experienced tremendous growth over the last couple of decades in all spectrums of financial activities including general banking, insurance (takaful), bonds (sukuk) and mortgages. Hesse et al. (2008) claim that this growth is fuelled by demand for Sharia compliant financial products from Middle East and other Muslim countries as well as global non-Muslim investors. The momentum of growth remained unaffected during the global recession and financial crisis and this has prompted a few to claim that IF is a viable option to conventional finance (Khan \& Bhatti, 2008). The developed economies, especially in Europe, have shown a keen interest in IF and countries like the UK, who have been pioneer of conventional banking and financial systems, have taken many steps in allowing the IF industry to emerge and grow (Malik et al., 2010).

In recent years, the demand for developments in the field of accounting to cater to the needs of this emerging financial system has been surging. It emerges that the existing accounting systems and standards are largely based on Anglo-American thoughts and are unfit for reporting purposes of Islamic financial and business organisations. The Accounting and Auditing Organisation for Islamic Financial Institutions (AAOIFI) is a body charged with the responsibility of developing Sharia compliant accounting standards for Islamic institutions. However, it is pertinent to note that most Islamic institutions are using IFRS as well as local standards based on conventional wisdom and philosophy.

\subsection{Underlying Principles}

Islamic religious law, known as Sharia, provides comprehensive and unquestionable guidance on all aspects of lives (Monger \& Rawashdeh, 2008) and IF rests on one of the general principles of Islamic religious beliefs, that economic activity should enhance social welfare (Hesse et al., 2008). Sharia is an Arabic word meaning 'the path to be followed'. It is a fundamental belief of all Muslims that Sharia is the path shown by Almighty Allah through His messenger, the Prophet Muhammad (PBUH). Quran, the holy book of Muslims dictates:

'We made for you a law, so follow it, and not the fancies of those who have no knowledge.' (65:18)

Islamic Law operates by exception, meaning that all is permitted unless expressly prohibited (Monger \& Rawashdeh, 2008). Islamic finance must therefore operate within the following five tenets that also serve to distinguish it from the conventional financial system. First and foremost is the prohibition of interest, second is the matching of risk and reward through profit and loss sharing techniques, third is the requirement that money is not made from money, fourth is the non-involvement of uncertainty and speculation in transactions and fifth is the prohibition of certain practices, such a commerce involving alcohol and gambling (Khan \& Bhatti, 2008).

The IF contracts are, therefore, asset-based transactions that comply with Sharia law, meaning that the relationships between financiers and borrowers are governed not through gains associated with the time value of money (interest) but by shared business risk and rewards from investment in lawful (Halal) activities (Hesse et al., 2008). Therefore instead of conventional banks' use of loans and other interest based products Islamic banks use profit-and-loss sharing arrangements, purchase and resale of goods and services, and the provision of services for fees (Kettell, 2010).

Given next is a summary (Table 1) of the sources of Sharia which also define and govern IF principles upon which IF commercial products and policies are based. It will be a helpful reference when the analysis is extended to CA. (For a fuller discussion on sources of Islamic jurisprudence see Hasan, 2004).

Table 1. Sources of Islamic Jurisprudence

\begin{tabular}{ll}
\hline Source & Explanation \\
\hline Primary & \\
Quran and Sunnah & $\begin{array}{l}\text { As Muslims consider Quran the word of God, it is the primary source of all laws in } \\
\text { Islamic jurisprudence, whether relating to religious or temporal matters. Where Quran is } \\
\text { silent on any issue then traditions of prophet (Sunnah) is considered to be the primary } \\
\text { source. All Muslims must, therefore, refer to Quran and Hadith for guidance on all } \\
\text { matters of life including economics and trade }\end{array}$ \\
Secondary & $\begin{array}{l}\text { Ijma means general consensus of noted Muslim jurists over issues which are not clearly } \\
\text { Ijma, Qiyas etc }\end{array}$ \\
& $\begin{array}{l}\text { Individual rulings or verdicts (Fatwa) on a new issue by creating an analogy with a } \\
\text { known and settled issue. For instance, Islam strictly prohibits taking photos. However, } \\
\text { Ijma allowed this to be taken for the necessary purposes of passport etc. }\end{array}$
\end{tabular}

Sources: Hasan (2004), Ayub (2007), Khan and Bhatti (2008), Malik et al. (2011) 


\subsection{Accounting and Accountants in Islam}

Accountability with accounting is one of the foundational principles of Islamic ideology. Falah, a comprehensive concept of explaining the purpose of a human life, guides the notion of accountability. Falah refers to success in this world as well as the one hereafter, the more permanent one (Yaya, 2004). The acts of humans in this world are being justly and accurately recorded by Allah and this accounting result will determine their fate on the Day of Judgement. The Muslims have absolute faith in the happening of Day of Judgement and balancing of good and bad deeds during their worldly life to determine whether they will go to hell or indeed heaven. The Quran clearly states:

"Allah takes careful account of all things". (Al Nisa 4:86)

The same is ordered for those entrusted for accounting roles in the society. The Quran orders:

"And give full measure when you measure, and weigh with a balance that is straight. That is good (advantageous) and better in the end". (Al-Isra' 17:35)

And Quran further stresses:

"Give full measure, and cause no loss (to others)". (Ash-Shu'ara 19:181)

In another verse, Quran says woe to those who measure unjustly and engage in fraud; they measure justly when they have to receive but measure unjustly when they to pay to others (Al-Mutaffifin, 83:1-3). This is the reason that accountants have always had a significant position in Islamic society. The earlier history of renaissance of Islam suggests that the most powerful position was held by accountants under various titles e.g. Katib al-Mal, Al-Katib; Muhasib, Muhtasib (see Abdul-Ghani et al., 2012). Ameer (2007) suggests that the definition of Islamic accounting is similar to that of conventional accounting, however, in doing so the accountants follow Sharia principles and keep Falah at the centre of their activities. The socio-economic objective at the heart of Islamic accounting is also a distinguishing feature. Hameed (2009) defines Islamic accounting as the process that provides appropriate information (not necessarily financial data) to stakeholders of an entity hence enabling them to ensure its continuous operation within the bounds of Islamic law, Sharia, and delivery of socio economic objectives.

Abdul-Ghani et al. (2012) conduct a comprehensive review of Islamic literature on the role and characteristics of an accountant. They have suggested the five distinguishing characteristics of Islamic accountant, and these could also be related to accountancy function in the society. First, Knowledge of Fiqah, as every Islamic accountant is required to have a detailed knowledge of Islamic jurisprudence. Second, Wara' (devotion), a religious dedication to prevent from engaging in violation of Islamic principles as well as knowledge to distinguish what is halal (permissible) and what is haram (unlawful). Third, Amanah (trustworthiness), a highly essential quality to act as a deputy of Allah on earth. The accountant must therefore be trustworthy and should follow superior ethics code as a trustee of stakeholders. Fourth, Itqan and Diqqah (perfection and precision), an Islamic accountant must be perfect and precise to ensure justice as ordered by Quran (Al-Anbiya, 21:47). Fifth, the accountant must be equipped with the necessary qualification, experience, skills and expertise do his/her job efficiently and effectively as Islam lays emphasis on meritocracy and abhors nepotism.

\section{Islamic Finance and Creative Accounting - Critical Discussion}

The IF model can be examined through the lens of CA at two levels; doctrinal and operational. We first carry our examination at the doctrinal level and then extend the analysis to the operational level to identify discrepancies and gaps if any.

The doctrinal level analysis is based upon the premise that in the Islamic set of core beliefs there is no division between the temporal and divine. Quran very clearly states that:

"Then when the prayer is finished, you may disperse through the land, and seek the Bounty of Allah (by working, etc.), and remember Allah much, that you may be successful." (Quran 62:10)

For Muslims Quran and Sunnah provide a complete code of life and hence socioeconomic spheres of their lives also need to be governed by the teachings of sharia which are sourced from Quran and Sunnah. No form of Islamic finance can therefore deviate from this rule as it will then be considered Haram (forbidden) under sharia.

Creativity in Islam can be seen in two different ways. In its positive connotation, Ijma or Qiyas (Table 1) can be cited as an example of critical and creative thinking as it aims at answering questions which are not well covered in the primary sources of sharia. This has helped Islamic jurisprudence to respond well to the issues of a complex modern society. The IF is also a product of this form of creative thinking. In its second way creativity is considered detrimental to the very fabric of the Muslim polity as it clashes with the core fundamentals of faith. 
Such a form of negative creativity is known as bid'ah and is discouraged as Muslims believe that Quran, being the word of God, cannot be modified. Quran says:

"Indeed, it is We who sent down the Qur'an and indeed, We will be its guardian. (Quran 15:9)."

So it can be argued that while creativity with a positive intent is not discouraged, negative creativity that intends to go against the basic tenets of the religion and potentially corrupt its fundamentals has no place in any system that draws its inspiration from Islam. As a part of regulatory requirements all IF products, offered by Islamic as well as conventional banks, therefore, must be certified as Halal (permissible according to Sharia Law) by an approved Islamic Scholar or Islamic Organization.

We now turn our focus upon the notion and practice of CA in the framework of IF at the doctrinal level. As already stated in section 3, CA is widely seen as a negative activity undertaken with a malicious intent to defraud, cheat, deceive, steal and misrepresent (Naser, 1993; Smith, 1996; Jones, 2011). This is in sharp contrast with the fundamental teachings of Islam that call for ethical conduct and fair dealing in trading activities. Committing fraud in any form is sinful as the Prophet Muhammad (PBUH) said:

"Sell the good and bad (things) separately. He who deceives is not of us". (Reported by Ahmad, cited in Al-Qaradawi, 2013)

"A man mentioned to the Messenger of Allah (may peace be upon him) that he was deceived in a business transaction, whereupon Allah's Messenger (may peace be upon him) said: When you enter into a transaction, say: There should be no attempt to deceive". (Sahih al-Bukhari, Book 10, Chapter 12, No 3663)

In Islamic code of ethics an action is only justifiable if it is done in good faith. Intent, therefore, is of paramount importance in Islamic finance.

"The reward of deeds depends upon the intentions and every person will get the reward according to what he has intended." (Sahih al-Bukhari, 1:1)

This means that if in financial transactions the intention of a doer is of deceit then even a seemingly legitimate action will become a sinful act. Prophet Muhammad (PBUH) himself was associated with trade and commerce as his first wife Khadijah was a businesswoman who had hired the services of Prophet Mohammad to look after business matters. Trade and ethical behaviour therefore finds an important place in Prophet's teachings. While encouraging greater participation in trade related activities, Muslims have been exhorted to conduct themselves in a fair and transparent way.

As IF is based on ethical considerations, honesty in all transactions is firmly encouraged. Honesty encourages truthfulness which can be incorporated in both personal and business matters. Traders are therefore required to highlight all features of a product or service and it is preferred to reveal any deficiencies in the product before attempting to influence the potential buyers. Fairness and justice are the essence of godliness according to Quran:

O ye who believe! Stand out firmly for justice, as witnesses to Allah, even as against yourselves, or your parents, or your kin, and whether it be (against) rich or poor: for Allah can best protect both. Follow not the lusts (of your hearts), lest ye swerve, and if ye distort (justice) or decline to do justice, verily Allah is well-acquainted with all that ye do. (Quran 4:135)

In another verse, Quran says:

O my people! Give full measure and full weight in justice, and wrong not people in respect of their goods. (Quran 11:85)

CA in contrast is about hiding the reality by presenting wrong and misleading information on business health and financial affairs (Griffith, 1995; Smith, 1996). CA practices thrive in a business market dominated by products and services marked by uncertainty and ambiguity. The financial innovations in the form of derivatives and other financial products are based on speculations or promises as no real assets might be backing them up. This synthetic activity gradually results in a financial bubble that is in danger of bursting at any time and hence endangering the whole market economy. The examples of Enron scam and the financial crisis of 2008 are highly pertinent here.

The recent financial crisis, to a great extent, can be related to financially engineered products. The principle of no Gharar (uncertainty) in IF model discourages profiteering from uncertainty. Those contracts where price, quantity, quality, and delivery are not certain are therefore not permissible under the IF model. The doctrinal foundation of IF is thus in sharp contrast to the practice of CA which often relies heavily on financially engineered and manipulated products. 
The importance of trust in business transactions cannot be overemphasised. In IF, trust finds a central place in the scheme of things as there are numerous sayings of Prophet that stress upon trustworthiness as a basic ingredient of a Muslim's religious faith.

"The trustworthy, honest Muslim merchant will be with the martyrs on the Day of Resurrection." (Sunan Ibn Majah Chapter 14, No 2139)

Prophet Muhammad further stresses that if someone dies in the state of dishonesty and distrust he is not from amongst us (Sahi al-Bukhari 50:832).This means that Muslims must practice honesty and trust in their everyday dealings including business transactions. Therefore, practices like CA that are against the principles of honesty and trust cannot be resorted to if the managers of an organization claim to be adhering to Sharia principles.

We are mindful of the fact that holy books of all faith followers make ethical considerations binding upon their believers. The mainstream finance however is secular in nature and makes no explicit or implicit references to any beliefs system. The IF model, on the other hand, markets its alternative financial system status solely on the basis of its claim of explicit adherence to the core principles of Islam. At the doctrinal level, as the review of the core teachings of Islam suggests, it can, therefore, be concluded that CA will not find currency in the organisations that claim to be working along IF principles. How the same question can be answered from operational level perspective? We examine this next.

There is not much reported research in the mainstream academic literature about CA in the IF industry. Some studies have, however, reported that income smoothing related practices are commonplace. For instance, Farook et al. (2012) after examining a sample of 66 Islamic banks from 12 Islamic countries report widespread use of income smoothing amongst Islamic banks. The authors find that factors such as religiosity, financial development, asset composition, and existence of discretionary reserves are positively related with profit distributions management of Islamic banks. Income smoothing was found to be negatively related with factors such as market familiarity with Islamic banking, market concentration, depositor funding reliance and the age of the Islamic bank. Some earlier studies also report use of earnings management in IFIs (e.g. Taktak et al., 2010; Ismail \& Lay, 2002). Arguably the unique scripture based financial system needs to employ earnings management at a greater scale as IFIs have to deal with risk sharing between investors and are thus under greater pressure to set up profit equalization and investment risk reserves to absorb any future losses (Taktak et al., 2010). A common practice is the use of a Profit Equalisation Reserve (PER) to hold back profits in good times and give more to depositors in less profitable years (PWC, 2010). However, such a reserve is bound to create many accounting treatment difficulties.

How transactions are to be reported for the purpose of control and accountability is an intensely debated issue in the IF (Hameed, 2000; Abul-Ghani et al., 2012). The Bahrain based AAOIFI is the regulating body to cater to the accounting needs of the IFIs. The AAOIFI has been trying to prescribe rules, requirements and restrictions that are compliant with Sharia in addition to satisfying accounting needs of IFIs. The AAOIFI's "Statement of Financial Accounting No. 1: Objectives of Financial Accounting for Islamic Banks and Financial Institutions" was published in 1993. The introduction to that statement says: "Financial accounting in Islam should be focused on the fair reporting of the entity's financial position and results of its operations, in a manner that would reveal what is halal (permissible) and haram (forbidden).

It is interesting to note that almost all countries which claim to be the hubs of Islamic finance have fully or partially adopted conventional finance based GAAP or IFRS (Amin, 2012). This is notwithstanding the fact that the flexibility in the accounting standards is often blamed as a major determinant of CA practices in the mainstream financial institutions (Baker \& Hayes, 2004). This resulted in a raging debate about 'substance over form' as various accounting standards setting bodies grappled with the slippery concept (Baker \& Hayes, 2004; Rutherford, 1985). There is a rising chorus which blames CA for many high profile corporate scams in the recent years. For instance, reviewing the case of Enron scam, Baker and Hayes (2004) argue that had the concept of substance over form been applied at Enron investors and creditors would have been saved from the adverse consequence of one of the largest corporate bankruptcies in US history.

While big accounting firms (e.g PWC, 2010; ACCA, 2010) do not see any problem in adoption of IFRS as the accounting framework by IFIs many authors have expressed their concern over this universal trend in the Muslim countries (e.g Haniffa \& Hudaib, 2010) as they contend that this would create opportunities for CA practices in the IF as well. Maurer (2010) revisits the debate over permissibility of sukuk financing and after examining the role of standard-setting bodies and rating agencies concludes that the financial markets promoted by neoliberal reforms pose an additional risk of blurring the differences between IF products and their conventional counterparts. 
CA practices also make inroads through the secondary source of Sharia Law which depends on subjective interpretations of Muslim scholars belonging to various schools of thought. One example of this tendency is what is popularly known as 'fatwa shopping'. There are critics (e.g. Wilson, 1999; Ahmad et al., 2010) who suggest that IFIs engage in window dressing and CA activities in order to present a newly designed product as Islamic when in reality it is a case of old wine in a new bottle. The critics allege that the designers of the new product shop around to obtain a 'fatwa', i.e. Islamic ruling so that necessary certification of sharia compliance is obtained for the product and thereby gain legitimacy among the potential buyers. Acobar (2010) refers to a study by a consultant for the fund industry which found that the top 10 scholars held about 46 percent of all available positions in the Gulf Arab region (Ünal, 2011). The same study reported that internationally, excluding the Gulf, the top 10 scholars - out of 70 active outside the region - held 58 percent of board positions. Foster (2009) refers to a candid observation of an investment banker based in Dubai, working for a major Western financial organisation:

"We create the same type of products that we do for the conventional markets. We then phone up a Sharia scholar for a Fatwa [seal of approval, confirming the product is Shari'ah compliant]. If he doesn't give it to us, we phone up another scholar, offer him a sum of money for his services and ask him for a Fatwa. We do this until we get Sharia compliance. Then we are free to distribute the product as Islamic."

While the use of earnings management techniques can be attributed to the peculiar nature of IFIs there are cases of accounting scams which have surfaced in countries where one expects strict implementation of IF core principles. Stories of a Saudi telecom company made headlines recently when it was revealed that about $\$ 380 \mathrm{~m}$ in previous profits had been misreported (Kerr, 2014). Some commentators of IF (e.g. Gulf Business, 2013) suggest that the IF industry would be rocked by Enron kind of incidents on account of poor risk-management and underdeveloped corporate governance culture.

\section{Conclusions}

IF stands out as a unique model among the alternative financial and accounting systems. It claims to be designed on ethical considerations which are drawn from the teachings of Quran and Holy Prophet. If this doctrinal lens is used to consider the possibility of CA flourishing in IF we can conclude that the answer is in the negative. This will have far reaching social implications as this will impede the society's view of IF as an ethical, equitable, fair and trustworthy system to conduct financial matters. The IF establishment endorses this principle time and again as is evident from the ruling given by the Sharia Advisory Council (SAC) of the central Bank of Malaysia in its publication on Islamic Finance where it considered the issue of 'substance over form':

".. in principle, "substance" and "form" are equally important and highly taken into consideration by the Shariah. In this regard, the Shariah emphasises that "substance" and "form" must be consistent and shall not contradict one another. In the event of inconsistency between "substance" and "form" due to certain factors, the Shariah places greater importance on "substance" rather than "form"”." (Bank Negara, 2010)

The ruling refers to one of the most important legal maxims of Islamic jurisprudence that matters are determined according to intentions of the doer. (Al-Zarqa, 1989, p. 47; Al-Nadwi, 2000, p. 550)

Instead of this deductive reasoning at the doctrinal level if we turn our attention to the operational and empirical side of the question we find three main factors that open the doors of the IF industry to the CA practices. One, most IFIs around the world, with the exception of Iran, have fully or partially adopted conventional accounting standards as well as new International Financial Reporting Standards (IFRSs). The flexibility in these accounting standards adopted by IFIs provide an opportunity for CA to gain ground as accountants and legal experts are good at manufacturing reality (Hines, 1988). El-Gamal, (2004), a known critic of IF products, questions the basic business model of IF contending that it is based on regulatory arbitrage where lawyers, bankers and jurists join hands to provide re-engineered versions of mainstream financial products by capitalising upon religious sentiments of the buyers. He mentions that as competition increases the need for reengineering becomes stronger to remain profitable in a small market. The fact that Muslim world is politically divided into various camps following different versions of Islamic theology makes it less likely that AAOIFI standards can be universally accepted. This is confirmed by Nor et al. (2015) who report after interviewing preparers of financial accounts of IFIs in Malaysia that differences in schools of Islamic jurisprudence did not permit adoption of AAOIFI standards in the country. Two, there is also a common criticism that IFIs are weakly administered and managed (Malik et al., 2011). Three, profit making is a rational activity and managers in IFIs are under pressure to deal successfully with investment risks and survive in a competitive market. Working within the constraints of IF, they, therefore, utilise all options to do profit maximisation which get manifested in practices like fatwa shopping and CA techniques. It has been claimed by critics and sceptics of IF that products like Tawarruq (that are generally 
considered to be non-sharia compliant) are packaged as Mubaraha financing (El-Gamal, 2004). The gap between theory and practice can be seen as significant when the doctrinal and operational level evidence are arrayed against one another (Maurer, 2010).

This paper has made a contribution to the literature by revisiting IF as an emerging accounting and financial system and examining it through the analytical lens of CA. Further research can make use of qualitative methods such as interviewing managers and accounting professionals working in IFIs to determine factors that promote adoption of CA practices in IFIs. Researching institutional level factors as determinants of CA practices and empirical analysis of the landscape of such practices can be an interesting extension of this under researched area.

\section{References}

Abdul-Ghani, A. R., Laluddin, H., Zian, M. N., \& Zakaria, Z. (2012). The New Breed of Islamic Accountants and Their Role in Islamic Institutions. Advances in Natural and Applied Sciences, 6(8), 1287-1295.

ACCA (2010). Accountancy futures: Harmonising financial reporting of Islamic finance: A collaboration between ACCA and KPMG. Retrieved April 10, 2017, from http://www.accaglobal.com/content/dam/acca/global/PDF-technical/financial-reporting/tech-af-hfrif.pdf

Ahmad, A., Rehman, K., \& Saif, M. I. (2010). Islamic Banking Experience of Pakistan: Comparison Between Islamic and Conventional Banks. International Journal of Business and Management, 5(2), 137-143. https://doi.org/10.5539/ijbm.v5n2p137

Alexander, D., \& Archer, S. (2003). On Economic Reality, Representational Faithfulness and the True and Fair Override. Accounting and Business Research, 33(1), 3-17. https://doi.org/10.1080/00014788.2003.9729628

Al-Nadwi, A. A. (2000). Al-Qawā’id Al-Fiqhiyyah. Dār Al-Qalam, Syria.

Al-Qaradawi, Y. (2013). The Lawful and the Prohibited in Islam. Islamic Book Trust. Kuala Lumpur.

Al-Zarqa, A. (1989). Syarh al-Qawa id al-Fiqhiyyah. Dar al-Qalam. Syria.

Ameer, S. (2007). Development of Islamic Accounting Theory: Principles of Shahdat Second Principle. International Review of Business Research Papers, 3(3), 56-68.

Amin, M. (2012). Islamic Financial Institutions and Implications of Accounting Under IFRS. New Horizon. Institute of Islamic Banking and Insurance.

Ayub, M. (2007). Understanding Islamic Finance. England: John Wiley \& Sons, Ltd.

Baker, C. R., \& Hayes, R. (2004). Reflecting form Over Substance: The Case of Enron Corp. Critical Perspectives on Accounting, 15, 767-785. https://doi.org/10.1016/j.cpa.2002.08.001

Bank Negara. (2010). Shariah Resolutions in Islamic Finance (2nd ed.). Retrieved April 15, 2017, from $\mathrm{http} / / / \mathrm{www} . b n m . g o v . m y / . . / /$ financial/pdf/resolutions/shariah_resolutions_2nd_edition_EN.pdf

Barreveld, D. (2002). The Enron Collapse: Creative Accounting, Wrong Economics or Criminal Acts? San Jose: Writers Club Press.

Blackaby, A. (2008). Non-Muslims Turn to Islamic Banks as a Safe Option. The Birmingham Post. Retrieved September 28, 2016, from http://www.birminghampost.net/birmingham-business/birmingham-businessnews/other-uk-business/2008/10/03/non-muslims-turn-to-islamic-bank-as-a-safe-option-65233-21962049/

Breton, G., \& Taffler, R. J. (1995). Creative Accounting and Investment Analyst Response. Accounting and Business Research, 25(98), 81-92. https://doi.org/10.1080/00014788.1995.9729931

Crumbley, L., \& Apostolou, N. (2003). The Accounting Profession and Financial Statement Fraud. The Forensic Examiner. January/February.

De La Torreo, I. (2009). Creative Accounting Exposed. Palgrave Macmillan. UK.

El-Gamal, M. A. (2004). Limits and Dangers of Shari'a Arbitrage. Retrieved April 10, 2016, from http://www.ruf.rice.edu/ elgamal/files/Arbitrage.pdf

Farook S., Hassan, K., \& Gregory, C. (2012). Profit Distribution Management by Islamic Banks: An Empirical Investigation. The Quarterly Review of Economics and Finance, 52(3), 333-347. https://doi.org/10.1016/j.qref.2012.04.007

Foster, J. (2009). How Sharia-Compliant is Islamic Banking? Retrieved August 12, 2017, from http://news.bbc.co.uk/1/hi/business/8401421.stm 
Gowthorpe, C., \& Blake, J. (1998). The Ethics of Creative Accounting. Quartermelon, UK.

Griffith, I. (1995). New Creative Accounting (2nd ed.). Mackays of Chatham Plc. UK. https://doi.org/10.1007/978-1-349-13649-0

Gulf Business. (2013). Will The Islamic Finance Industry Witness A Scandal In 2014? Retrieved October 20, 2017, from http://gulfbusiness.com/2013/12/will-the-islamic-finance-industry-witness-a-scandal-in-2014/\#. VdSEO9FwbIU

Hameed, S. H. M. I. (2000). Nurtured by kufr: The Western Philosophical Assumptions Underlying Conventional (Anglo-American) Accounting. International J. of Islamic Financial Services, 2(2), 19-37.

Hameed, S. H. M. I. (2009). Accounting and Auditing for Islamic Financial Institutions (1st ed.). Kuala Lumpur: INCEIF.

Haniffa, R., \& Hudaib, M. (2010). The Two Ws of Islamic accounting research. Journal of Islamic Accounting and Business Research, 1(1), 5-9. https://doi.org/10.1108/17590811011033370

Hasan, A. (2004). Principles of modern Islamic jurisprudence. Academy of Jurists. Karachi, Pakistan.

Hesse, H., Jobst, A. A., \& Sole, J. (2008). Trends and Challenges in Islamic Finance. World Economics, 9(2), 175-194.

Hines, R. (1988). Financial Accounting: In Communicating Reality, We Construct Reality. Accounting, Organizations and Society, 13(3), 251-261. https://doi.org/10.1016/0361-3682(88)90003-7

Ismail, A. G., \& Lay, T. B. (2002). Bank Loan Portfolio Composition and the Disclosure of Loan Loss Provisions: Empirical Evidence from Malaysian Banks. Asian Review of Accounting, 10(1), 147-162. https://doi.org/10.1108/eb060754

Jones, M. (2011). Creative Accounting, Fraud and International Accounting Scandals. London: Wiley.

Kamla, R. (2009). Critical Insights into Contemporary Islamic Accounting. Critical Perspective on Accounting, 20(8), 921-932. https://doi.org/10.1016/j.cpa.2009.01.002

Karbhari, Y., Naser, K., \& Shahin, Z. (2004). Problems and Challenges Facing the Islamic Banking System in the West: The Case of the UK. Thunderbird International Business Review, 46(5), 521-543. https://doi.org/10.1002/tie.20023

Kerr, S. (2014, November 24). CEO Suspended at Saudi Telecoms Group Hit by Accounting Scandal. The Financial Times.

Kettell, B. (2010). Islamic Finance in a Nutshell: A Guide for Non-Specialists. The Wiley Finance Series. John Wiley \& Sons, UK.

Khan, M. M., \& Bhatti, M. I. (2008). Islamic Banking and Finance: On Its Way to Globalization. Managerial Finance, 34(10), 7008-725.

Mainelli, M. (2012). The Battle of Accountancy Has Begun. The Financial Times. 29 July 2012.

Malik, A., Malik, M. S., \& Shah, H. (2010). An Analysis of Islamic Banking in the West: From Lagging to Leading. Asian Social Science, 7(1), 179-185. https://doi.org/10.5539/ass.v7n1p179

Malik, M. S., Malik, A., \& Mustafa, W. (2011). Controversies that Make Islamic Finance Controversial: An Analysis of Issues and Challenges. American Journal of Social and Management Sciences, 2(1), 41-46. https://doi.org/10.5251/ajsms.2011.2.1.41.46

Maurer, B. (2010). Form versus substance: AAOIFI projects and Islamic fundamentals in the case of sukuk. J. of Islamic Accounting \& Business Research, 1(1), 32-41. https://doi.org/10.1108/17590811011033398

Minkow, B. (1995). Clean Sweep: The Inside Story of the Zzzz Best Scam... One of Wall Street's Biggest Frauds. Thomas Nelson Inc.

Monger, R., \& Rawashdeh, M. (2008). Islamic Finance Enters the Mainstream. Management Accounting Quarterly, 8(3), 1-6.

Mulford, C. W., \& Comiskey, E. E. (2002). The Financial Numbers Game: Detecting Creative Accounting Practice. Wiley, New York.

Naser, K. H. M. (1993). Creative Financial Accounting. Prentice Hall International, UK.

Nor, F. M., Fadzlina, M. F., \& Asyaari, E. A. (2015). The influence of AAOIFI Accounting Standards in 
Reporting, Islamic Financial Institutions in Malaysia. Procedia Economics and Finance, 31, 418-424. https://doi.org/10.1016/S2212-5671(15)01216-2

Popescu, L. M., \& Nisulescu, I. A. (2013). Detecting Creative Accounting Practices and Their Impact on the Quality of Information Presented in Financial Statements. Journal of Knowledge Management, Economics and Information Technology, 3(6), 1-13.

PWC (2010). Open to comparison: Islamic finance and IFRS. Retrieved July 31, 2017, from http://www.pwc.co.uk/assets/pdf/open-to-comparison-islamic-finance-and-ifrs.pdf

Rutherford, B. (1985). The true and fair view doctrine: A search for explication. Journal of Business Finance \& Accounting, 12(4), 483-494. https://doi.org/10.1111/j.1468-5957.1985.tb00788.x

Sahih Al-Bukhari. Book 1, Hadith 1. Retrieved September 10, 2017, from http://sunnah.com/bukhari/1

Samuel, J. M., Rickwood, C., \& Piper, A. G. (1989). Advanced Financial Accounting (2nd ed.). McGraw Hill, London.

Schilit, H. (2002). Financial Shenanigans: How to Detect Accounting Gimmicks and Fraud in Financial Reports. McGraw-Hill, New York.

Smith, T. (1996). Accounting for Growth: Stripping the Camouflage from Company Accounts (2nd ed.). Century Business, London.

Spellman, J. D. (2012). Bad Governance to Blame for Creative Accounting. The Financial Times.

Taktak, N., Sana, Z., \& AbdelKader, B. (2010). Do Islamic Banks Use Loan Loss Provisions to Smooth Their Results? Journal of Islamic Accounting and Business Research, 1(2), 114-127. https://doi.org/10.1108/17590811011086714

Tweedie, D. P., \& Whittington, G. (1990). Financial reporting: Current problems and their implications for systematic reform. Accounting and Business Research, 21(81), 87-102. https://doi.org/10.1080/00014788.1990.9729407

Ünal, M. (2011). The Small World of Islamic Finance- Sharia Scholars and Governance: A Network Analytic Perspective, Funds @ Work, Retrieved August 23, 2017, from http://www.funds-at-work.com/intelligence/research-publications.html

Uysal, O. Z. (2010). Business Ethics Research with an Accounting Focus: A Bibliometric Analysis from 1988 to 2007. Journal of Business Ethics, 93(1), 137-160. https://doi.org/10.1007/s10551-009-0187-9

Wilson, R. (1999). Challenges and Opportunities for Islamic Banking and Finance in the West: The UK experience. Islamic Economic Studies, 7(1\&2), 16-32.

Wilson, S. (1969). Thinking with Concepts. Cambridge, U.K.: Cambridge University Press.

Yaday, B. (2014). Creative Accounting: An Empirical Study from professional Prospective. International Journal of Management and Social Sciences Research, 3(1), 38-53.

Yaya, R. (2004). Would the Objectives and Characteristics of Islamic Accounting for Islamic Business Organizations Meet the Islamic Socio-Economic Objectives? Jurnal Akuntansi \& Auditing Indonesia (JAAI), $8(2), 141-163$.

\section{Copyrights}

Copyright for this article is retained by the author(s), with first publication rights granted to the journal.

This is an open-access article distributed under the terms and conditions of the Creative Commons Attribution license (http://creativecommons.org/licenses/by/4.0/). 